\title{
Identification and quantification of 12 pharmaceuticals in water collected from milking parlors: Food safety implications
}

\author{
María Veiga-Gómez, Carolina Nebot, ${ }^{1}$ Carlos Manuel Franco, Jose Manuel Miranda, Beatriz Vázquez, \\ and Alberto Cepeda \\ Department of Analytical Chemistry, Nutrition and Bromatology, Faculty of Veterinary Medicine, Universidade de Santiago de Compostela, \\ Pavillón 4, Planta Baixa, 27002 Lugo, Spain
}

\begin{abstract}
The introduction of drug residues into the food chain and their presence in drinking water has been recently investigated. The aim of this work was to monitor the presence of 19 active drugs in water samples collected from milking parlors of dairy farms located in Galicia (northwest Spain), one of the main Spanish milking areas. Overall, $65 \%$ of the samples tested positive for at least one of the compounds analyzed. A total of 12 drugs were measured, with concentrations ranging between 17 and $3,941 \mathrm{ng} / \mathrm{L}$. Considering that a mixture of compounds may contribute to the overall effect of each compound and might increase or reduce its toxicity, it should be noted that $29 \%$ of the samples tested contained more than one pharmaceutical. To date, the effects of the continuous consumption of these mixtures of drugs in water or milk are unknown; however, antimicrobials may affect the human gut microbiota or have toxic effects in sensitive individuals.
\end{abstract}

Key words: residue, drinking water, dairy farms, antimicrobial

\section{INTRODUCTION}

Pharmaceuticals are important and essential elements in life because they are used in agriculture, human, and veterinary medicine. According to the European Federation of Animal Health (FEDESA, 1998), the annual consumption of antibiotics in the European Union (EU) is about 13,000 t, with about $65 \%$ used in human medicine, $29 \%$ in veterinary medicine, and $6 \%$ used as food additives. The use of these substances in animal production is a common practice, not only for therapeutic purposes but also for prophylactic treatments (Iglesias et al., 2014). Once consumed, pharmaceuticals

Received October 28, 2016.

Accepted January 6, 2017.

${ }^{1}$ Corresponding author: carolina.nebot@usc.es are metabolized and part of the initial dose is excreted unchanged, with the higher percent excreted in the form of metabolites; both the parent compound and metabolites are excreted via feces and urine in both human and animals (Jjemba, 2006). These substances can therefore reach the aquatic environment through wastewater treatment plants because the plants are not able to remove them completely (Kosma et al., 2014). Another way of introducing these active compounds is through the use of contaminated manure in agricultural soils as fertilizer, contaminating rivers, lakes, and drinking water sources (Watkinson et al., 2009; Rodil et al., 2012). Additionally, during the manufacture and production of drugs, the environment can be contaminated with pharmaceuticals due to breaks, leaks, and uncontrolled washes (Rodil et al., 2012). Depending on the physicochemical properties of drugs and the characteristics of the water and soil, these active substances reach the environment, particularly the water system, through water runoff and leaking, contaminating aquifers, rivers, lakes, seas (Ayscough et al., 2000) and even human drinking water (Watkinson et al., 2009; Iglesias et al., 2014).

Farms across the European Union produced approximately 147,904 million tonnes of cow milk in 2014 (Eurostat, 2014); in particular, Spain produced 6,679 million tonnes. Galicia, in northwest Spain, is an area with high milk production at 2.65 million tonnes $(36.6 \%$ of the total produced in Spain; MAGRAMA, 2014) and has 14,415 livestock and 450,271 head of cattle (IGE, 2014). Water is very important on dairy farms, not only because it is used to feed animals but also for cleaning the facilities. Inadequate quality of the water used on dairy farms can lead to food safety concerns, because water contaminated with pharmaceuticals can come in contact with milk during equipment cleaning (Llena, 2011). In general, milk farms use water from public distribution, but the use of water from water wells is also common practice in Spain, particularly in Galicia. European legislation states that "water for cleaning food facilities shall be potable water" (Regulation 
853/2004; EU, 2004), because this water is in contact with food. In Spain, health criteria for water quality for human consumption are regulated by the Spanish standard Real Decreto 1120/2012 (BOE, 2012) and EU Directive 2015/1787 (EU, 2015).

If even small amounts of water carrying pharmaceuticals remain in the milk tank after cleaning, the new fresh milk would also be contaminated with these pharmaceuticals. The amount of water that remains in the tank is variable, depending on the size of the tank and the quality of the water system tubing; leaks due to broken valves can result in more water remaining compared with the residual left after cleaning. Milk could also contain residues of pharmaceuticals as a result of overdosing cattle treatment, incorrect separation of milk from medicated and unmediated animals, dry cow therapy anomalies, and, to a lesser extent, inadequate withdrawal period (MAGRAMA, 2005). Thus, methods for analysis of pharmaceuticals in milk exist to control and prevent food safety problems as much as possible. Maximum residue limits of pharmaceuticals allowed in foods of animal origin within the EU are provided in Regulation 37/2010 (EU, 2004). However, pharmaceuticals are not usually controlled in the water used for cleaning facilities, although legislation states that cleaning water used on farms should be of the same quality as human drinking water.

Even if the concentration of pharmaceuticals in the final milk is low and below the level set for antimicrobials in Regulation 37/2010 (EU, 2004), the unknown consumption of pharmaceuticals in this way may lead to interactions with knowingly consumed drugs or by increasing or reducing the effects of the prescribed drugs (Pomati et al., 2008). In the particular case of antimicrobials, continuous consumption of low levels of these active compounds can lead to the development of bacteria with resistance genes in consumers, which may result in synergistic or antagonistic effects and the need to increase or decrease the dose of the treatment (De Liguoro et al., 2009). Additionally, these substances can have harmful effects on the environment; for example, the synergistic activity of sulfamethoxazole and trimethoprim results in greater inhibition of the growth of the alga Selenastrum capricornutum compared with the respective individual activities (Santos et al., 2010). Therefore, low levels of active compounds could have negative effects on sensitive consumers, such as infants, the elderly, and allergic individuals who are frequent consumers of milk.

In accordance with the above data, research into the presence of pharmaceuticals in water used to clean milking facilities is needed. The aim of this study was to collect water from dairy farms located in the province of Lugo, one of the main milking areas in Spain, and to investigate the presence of 19 pharmaceuticals by using solid-phase extraction and HPLC-tandem mass spectrometry (MS/MS).

\section{MATERIALS AND METHODS}

\section{Study Area}

The weather in the area is classified as continental oceanic with an average temperature of $13.6^{\circ} \mathrm{C}$. The relief is very heterogeneous, constantly altering elevations and depressions, where the surface is broken by rivers or streams. The average rainfall is $678 \mathrm{~mm} / \mathrm{yr}$ (Meteogalicia, 2015). Table 1 shows average climatological data (temperature, relative humidity, rain, light hours, and hydric balance) of the province of Lugo over a 17-wk period from February to June 2015. The region investigated was divided into areas (Figure 1): South (1 sample), Coast (6 samples), Mountain (7 samples), Flatland (15 samples), and Center (23 samples).

\section{Chemicals, Reagents, and Stock Solutions}

Methanol and acetonitrile (HPLC grade, $\geq 99.9 \%$ ) were purchased from Scharlau Chemie (Barcelona, Spain), formic acid (purity, $>99 \%$ for analysis) from Acros Organics (Geel, Belgium), and hydrochloric acid solution $(0.1 \mathrm{~N} \mathrm{HCl})$ from Merck (Darmstadt, Germany). Nitrogen gas (purity, $>99.98 \%$ ) was generated by an in-house nitrogen generator from Peak Scientific Instruments Ltd. (Chicago, IL), and purified water was prepared in-house with a Milli-Q water system

Table 1. Climatological data for Lugo (Spain) during the months of water sample collection

\begin{tabular}{lccccc}
\hline $\begin{array}{l}\text { Sampling } \\
\text { month }\end{array}$ & $\begin{array}{c}\text { Average } \\
\text { temperature }\left({ }^{\circ} \mathrm{C}\right)\end{array}$ & $\begin{array}{c}\text { Average relative } \\
\text { humidity }(\%)\end{array}$ & $\begin{array}{c}\text { Rain } \\
\left(\mathrm{L} / \mathrm{m}^{2}\right)\end{array}$ & $\begin{array}{c}\text { Sunlight } \\
\text { hours }(\mathrm{h})\end{array}$ & $\begin{array}{c}\text { Hydric } \\
\text { balance }(\mathrm{L} / \mathrm{m})\end{array}$ \\
\hline February & 5.55 & 83.74 & 4.78 & 10.12 & 3.67 \\
March & 7.77 & 68.34 & 1.29 & 10.40 & -0.70 \\
April & 11.84 & 75.82 & 3.55 & 12.98 & -0.81 \\
May & 14.33 & 72.80 & 1.17 & 14.01 & -3.32 \\
June & 17.36 & 73.53 & 0.56 & 14.71 & -4.65 \\
Average & 11.37 & 74.84 & 1.61 & 12.44 & -1.16 \\
\hline
\end{tabular}


from Millipore (Bedford, MA). The internal standards sulfadoxine- $\mathrm{d}_{3}$ and robenidine- $\mathrm{d}_{8}$ and the pharmaceuticals betamethasone, cortisone, decoquinate, enrofloxacin, flumethasone, griseofulvin, maduramycin,

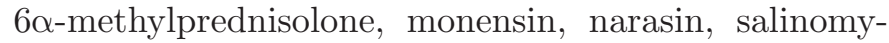
cin, sulfachloropyridazine, sulfadiazine, sulfamethazine, sulfamethizole, sulfamethoxazole, sulfamethoxypyridazine, sulfapyridine, sulfaquinoxaline, trimethoprim were purchased from Sigma-Aldrich (St. Louis, MO), all with purity $>98 \%$. The drugs were accurately weighed to prepare stock solutions of individual compounds at a concentration of $0.8 \mathrm{mg} / \mathrm{mL}$ in methanol. Stock solutions of the individual compounds were then mixed with $0.1 \%$ formic acid in methanol to obtain stock solutions of $10 \mu \mathrm{g} / \mathrm{mL}$; these solutions were further diluted with $0.1 \%$ formic acid in methanol to obtain standard mixtures of drugs at 75,150 , and $300 \mathrm{ng} / \mathrm{mL}$. All standard solutions were stored in the dark at $-18^{\circ} \mathrm{C}$ for a maximum of 6 mo.

The stock solutions of individual drugs at $0.8 \mathrm{mg} /$ $\mathrm{mL}$ were mixed to obtain a working stock solution of 1 $\mu \mathrm{g} / \mathrm{mL}$ with $0.1 \%$ formic acid in methanol. The therapeutic and chemical properties of the selected drugs are presented in Table 2.

\section{Equipment}

A MS2 Minishaker vortex mixer from IKA (Staufen, Germany), a vacuum station manifold and Strata-X solid-phase extraction (SPE) cartridges $(60 \mathrm{mg}, 3 \mathrm{~mL}$ ) from Phenomenex (Macclesfield, UK), and a Turbo Vap II evaporator from Zyrmark (Hopkinton, MA) were used for sample preparation and extraction.

Samples were analyzed on a liquid chromatographyMS/MS system consisting of an HPLC 1100 separation module from Agilent Technologies (Waldbronn, Germany), equipped with a vacuum degasser and an autosampler, and an API 4000 mass spectrometer from Applied Biosystems/MDS Sciex (Toronto, Canada) equipped with a TurboIonSpray source. The Software Analyst 1.6 from Applied Biosystems was used to control the system. The chromatographic analyses were performed

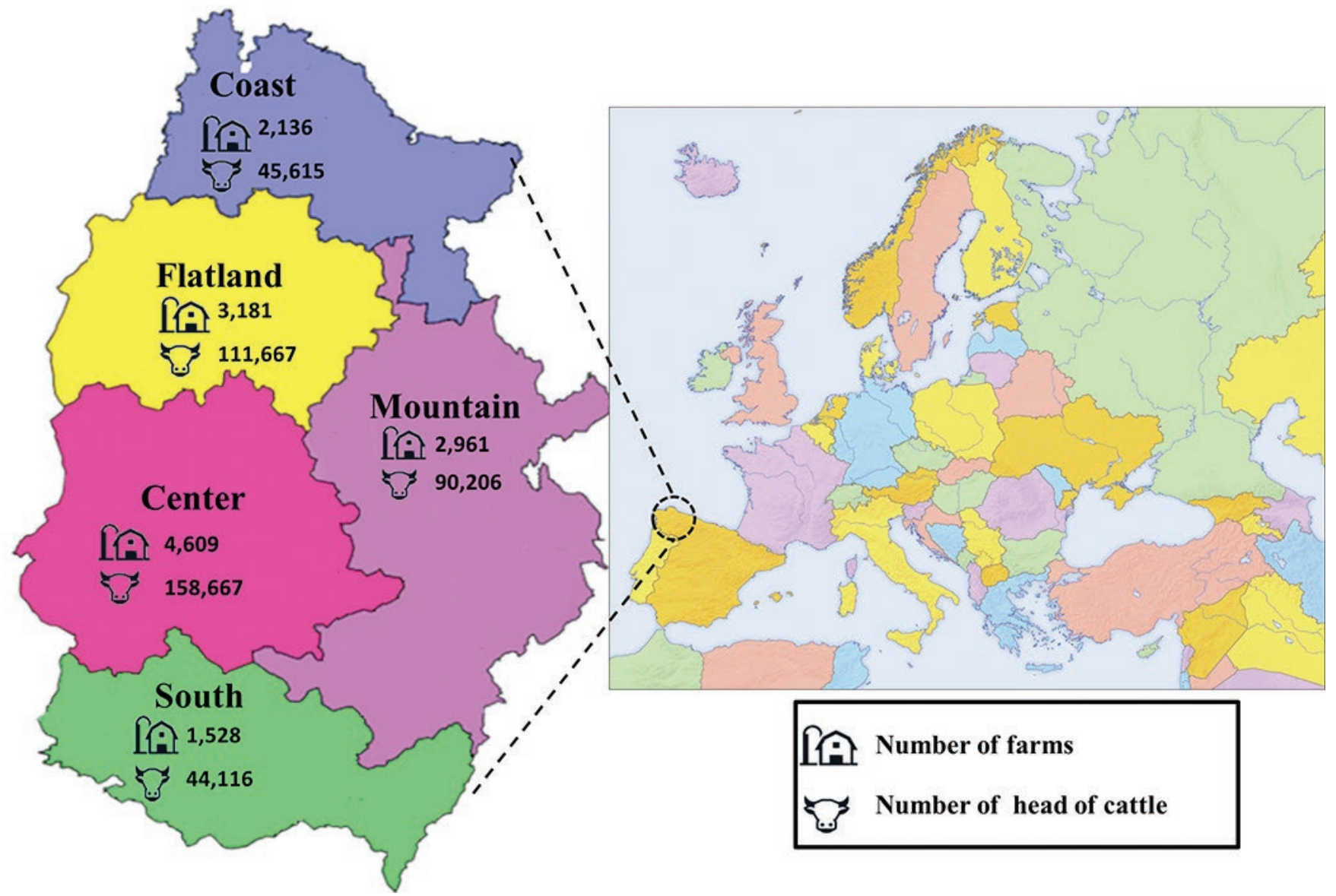

Figure 1. Map of the study area. Color version available online. 
Table 2. Therapeutic class and limit of quantification (LOQ) of selected veterinary drugs

\begin{tabular}{llll}
\hline Analyte & Therapeutic class & LOQ (ng/L) & Formula \\
\hline Betamethasone & Glucocorticosteroid & 12.5 & $\mathrm{C}_{22} \mathrm{H}_{29} \mathrm{FO}_{5}$ \\
Cortisone & Corticosteroid & 12.5 & $\mathrm{C}_{21} \mathrm{H}_{28} \mathrm{O}_{5}$ \\
Decoquinate & Coccidiostats & 12.5 & $\mathrm{C}_{24} \mathrm{H}_{35} \mathrm{NO}_{5}$ \\
Enrofloxacin & Antimicrobial & 25.0 & $\mathrm{C}_{19} \mathrm{H}_{22} \mathrm{FN}_{3} \mathrm{O}_{3}$ \\
Flumethasone & Corticosteroid & 25.0 & $\mathrm{C}_{22} \mathrm{H}_{28} \mathrm{~F}_{2} \mathrm{O}_{5}$ \\
Griseofulvin & Antifungal & 25.0 & $\mathrm{C}_{17} \mathrm{H}_{17} \mathrm{ClO}_{6}$ \\
Maduramycin & Coccidiostats & 12.5 & $\mathrm{C}_{47} \mathrm{H}_{83} \mathrm{NO}_{17}$ \\
6a-Methylprednisolone & Corticosteroid & 25.0 & $\mathrm{C}_{22} \mathrm{H}_{30} \mathrm{O}_{5}$ \\
Monensin & Coccidiostats & 12.5 & $\mathrm{C}_{36} \mathrm{H}_{62} \mathrm{O}_{11}$ \\
Narasin & Coccidiostats & 12.5 & $\mathrm{C}_{43} \mathrm{H}_{72} \mathrm{O}_{11}$ \\
Salinomycin & Coccidiostats & 12.5 & $\mathrm{C}_{42} \mathrm{H}_{70} \mathrm{O}_{11}$ \\
Sulfachloropyridazine & Antimicrobial & 12.5 & $\mathrm{C}_{10} \mathrm{H}_{9} \mathrm{ClN}_{4} \mathrm{O}_{2} \mathrm{~S}$ \\
Sulfadiazine & Antimicrobial & 25.0 & $\mathrm{C}_{10} \mathrm{H}_{10} \mathrm{~N}_{4} \mathrm{O}_{2} \mathrm{~S}$ \\
Sulfamethazine & Antimicrobial & 25.0 & $\mathrm{C}_{12} \mathrm{H}_{14} \mathrm{~N}_{4} \mathrm{O}_{2} \mathrm{~S}$ \\
Sulfamethizole & Antimicrobial & 25.0 & $\mathrm{C}_{9} \mathrm{H}_{10} \mathrm{~N}_{4} \mathrm{O}_{2} \mathrm{~S}_{2}$ \\
Sulfamethoxypyridazine & Antimicrobial & 12.5 & $\mathrm{C}_{11} \mathrm{H}_{12} \mathrm{~N}_{4} \mathrm{O}_{3} \mathrm{~S}$ \\
Sulfapyridine & Antimicrobial & 25.0 & $\mathrm{C}_{11} \mathrm{H}_{11} \mathrm{~N}_{3} \mathrm{O}_{2} \mathrm{~S}$ \\
Sulfaquinoxaline & Antimicrobial & 25.0 & $\mathrm{C}_{9} \mathrm{H}_{9} \mathrm{~N}_{3} \mathrm{O}_{2} \mathrm{~S}_{2}$ \\
Trimethoprim & Antimicrobial & 12.5 & $\mathrm{C}_{14} \mathrm{H}_{18} \mathrm{~N}_{4} \mathrm{O}_{3}$ \\
\hline
\end{tabular}

by injecting $10 \mu \mathrm{L}$ of extract into a Synergi $2.5 \mu \mathrm{m}$ Polar-RP $100 \mathrm{~A}$ column $(50 \times 2.0 \mathrm{~mm})$ connected to a Polar-RP security-guard cartridge $(4.0 \times 2.0 \mathrm{~mm})$, both obtained from Phenomenex.

\section{Water Samples}

Water samples collected for this research were cleaning water collected in the milking parlors of 52 milking farms from the province of Lugo (Figure 1). The samples were from private water wells $(52 \%$ of the samples), from distribution systems (17\%), from both sources as the farm has access to both water systems $(4 \%)$, and unknown origin (27\%). Water samples were collected in 1-L polyethylene plastic vessels for pharmaceutical detection and in $150-\mathrm{mL}$ polyethylene plastic containers for microbial analyses. Within $4 \mathrm{~h}$ after collection, water samples were transported cooled to the laboratory and stored at $4^{\circ} \mathrm{C}$ until sample preparation for analysis. Because European legislation establishes that the quality of the water used in milking facilities should be potable (i.e., of the same quality as drinking water), hereafter, we refer to samples as water or drinking water.

\section{Sample Preparation}

To remove suspended solids, water samples were filtered $(800 \mathrm{~mL})$ under vacuum using a $0.47-\mu \mathrm{m}$ glass microfiber filter from Filter-Lab (La Rioja, Spain). The samples were acidified with $0.1 \mathrm{~N} \mathrm{HCl}$ to a $\mathrm{pH}$ of 3. After treatment, the samples were stored at $-18^{\circ} \mathrm{C}$ until analysis.

\section{Extraction Procedure}

For quantification, 4 control samples were acidified, fortified, and extracted following the same analytical procedure as the experimental samples. These control samples include a blank (tap water) and 3 fortified samples (tap water enriched with drugs) at 75, 150, and $300 \mathrm{ng} / \mathrm{L}$, respectively. Before extraction, experimental and control samples were spiked with $10 \mu \mathrm{L}$ of the internal standard (sulfadoxine- $\mathrm{d}_{3}$ and robenidine- $\mathrm{d}_{8}$ ) solution $(1 \mu \mathrm{g} / \mathrm{mL})$ and then shaken and transferred into the conditioned cartridges at a flow rate of $1 \mathrm{~mL} / \mathrm{min}$.

The extraction procedure was conducted based on Iglesias et al. (2012). Briefly, cartridges were conditioned with $4 \mathrm{~mL}$ of methanol and $4 \mathrm{~mL}$ of Milli-Q water. After loading the whole volume of sample $(0.8$ $\mathrm{L})$, the cartridges were dried under vacuum for $30 \mathrm{~min}$. Sample vessels were rinsed with $4 \mathrm{~mL}$ of methanol, which was transferred to the SPE cartridges and left to soak for $5 \mathrm{~min}$; the eluent was collected in a $10-\mathrm{mL}$ conical graduated Pyrex glass tube $(16.5 \times 110 \mathrm{~mm})$. Elution was completed with the addition of $4 \mathrm{~mL}$ of methanol, and the final mixture of eluents was evaporated to dryness under a stream of air at $45^{\circ} \mathrm{C}$. The dried extracts were reconstituted with $200 \mu \mathrm{L}$ of $0.1 \%$ formic acid in methanol, vortexed, and transferred into a $300-\mu \mathrm{L}$ glass insert, fused into an amber $2-\mathrm{mL}$ screwtop standard vial $(12 \times 32 \mathrm{~mm})$ and stored at $-18^{\circ} \mathrm{C}$ until analysis by HPLC-MS/MS.

\section{HPLC-MS/MS Method}

The HPLC method was conducted following Iglesias et al. (2012). Analytes were separated using a gradient 
Table 3. Retention time $\left(t_{R}\right)$ and precursor and product ions used to identify the selected drugs

\begin{tabular}{lcccc}
\hline Analyte & $\begin{array}{c}\mathrm{t}_{\mathrm{R}} \\
(\mathrm{min})\end{array}$ & $\begin{array}{c}\text { Precursor } \\
(\mathrm{m} / \mathrm{z})\end{array}$ & $\begin{array}{c}\text { Product } 1 \\
(\mathrm{~m} / z)\end{array}$ & $\begin{array}{c}\text { Product } 2 \\
(\mathrm{~m} / \mathrm{z})\end{array}$ \\
\hline Betamethasone & 15.3 & 393 & 355 & 373 \\
Cortisone & 14.8 & 361 & 163 & 121 \\
Decoquinate & 20.1 & 418 & 372 & 204 \\
Enrofloxacin & 13.1 & 360 & 342 & 316 \\
Flumethasone & 15.7 & 411 & 391 & 253 \\
Griseofulvin & 17.2 & 353 & 285 & 647 \\
Maduramycin & 22.3 & 935 & 629 & 161 \\
6a-Methylprednisolone & 15.2 & 375 & 339 & 479 \\
Monensin & 21.7 & 693 & 461 & 531 \\
Narasin & 22.5 & 787 & 431 & 531 \\
Salinomycin & 21.8 & 773 & 431 & 92 \\
Sulfachloropyridazine & 13.9 & 285 & 156 & 92 \\
Sulfadiazine & 10.9 & 251 & 156 & 92 \\
Sulfamethazine & 12.4 & 279 & 186 & 92 \\
Sulfamethizole & 13.0 & 271 & 156 & 92 \\
Sulfamethoxypyridazine & 12.9 & 281 & 156 & 92 \\
Sulfapyridine & 11.3 & 250 & 156 & 123 \\
Sulfaquinoxaline & 15.3 & 301 & 156 & \\
Trimethoprim & 11.9 & 291 & 230 & \\
\hline
\end{tabular}

mixture of 2 components and a flow rate of $0.15 \mathrm{~mL} /$ min; component A was $0.1 \%$ formic acid in acetonitrile and component $\mathrm{B}$ was $0.1 \%$ formic acid in water. Massspectrometry measurements were performed using positive electrospray $\left(\mathrm{ESI}^{+}\right)$, and pharmaceuticals were identified using 2 multiple reaction monitoring transitions and their retention times. The retention times and precursor and product ions used are summarized in Table 3.

\section{Microbiological Determinations}

The microbiological quality of water samples was investigated for the presence of total aerobic mesophilic and total coliform microorganisms. To determine total aerobic mesophilic counts, $1 \mathrm{~mL}$ of water was pourplated onto $15 \mathrm{~mL}$ of plate count agar, which was prepared following the manufacturer's instructions (Biolife, Milan, Italy) and subsequently incubated at $30^{\circ} \mathrm{C}$ for $72 \mathrm{~h}$. All colonies were counted to obtain the total aerobic mesophilic count. Coliform determinations were made by aseptically filtering $100 \mathrm{~mL}$ of water through a $45-\mu \mathrm{m}$ filter (Millipore). Then, filters were placed on a Petri plate and overlaid with $15 \mathrm{~mL}$ of violet red bile lactose agar, prepared following the manufacturer's instructions (Merck), and subsequently incubated at $24^{\circ} \mathrm{C}$ for $30 \mathrm{~h}$. After incubation, pink to red colonies were considered to be coliforms and taken as a positive result.

\section{Statistical Analysis}

The results were analyzed using the PAWS Statistics 18 SPSS Software Inc. (Chicago, IL) to identify statisti- cally significant trends in the drug concentration. The effects of weather conditions (Table 1), sampling date, and localization were tested using one-way ANOVA with significant differences at a $95.0 \%$ confidence level $(P$-values $<0.05)$.

\section{RESULTS AND DISCUSSION}

\section{Presence of Pharmaceuticals in Water Samples}

Out of the 19 pharmaceuticals analyzed, 12 were detected in water used for cleaning milking parlors, which should be of potable water quality. Betamethasone, decoquinate, enrofloxacin, monensin, salinomycin, sulfachloropyridazine, sulfadiazine, sulfamethazine, sulfamethoxypyridazine, sulfapyridine, sulfaquinoxaline, and trimethoprim were detected in water samples. These pharmaceuticals belong to 3 of most widely used therapeutic groups: antimicrobials, coccidiostats, and corticosteroids. Contamination of the samples investigated may be caused by contamination of the water source, such as rivers, lakes, and water wells via the discharge of incompletely clean final effluent from wastewater treatment plants (Chang et al., 2007; Kosma et al., 2014) or due to the application of manure over culture lands as fertilizer (Díaz-Cruz and Barceló, 2006; Baquero et al., 2008), which is common practice in the area. Additionally, the adsorption of the pharmaceuticals present in the environment to soil particles delays biodegradation and explains the long-term survival of drugs in the environment (Baquero et al., 2008); specifically, sulfadiazine and trimethoprim can persist for months or years depending on the sediment and they are highly persistent (Kasprzyk-Hordern et al., 2008). 
The pharmaceuticals cortisone, flumethasone, griseofulvin, maduramycin, 6 $\alpha$-methylprednisolone, narasin, and sulfamethizole were not detected. There might be several reasons for this, including chemical properties of the compounds, their minimal use in veterinary or human medicine, or their presence at concentrations below the limit of detection of the method used.

Antimicrobials were the most frequently detected group: sulfonamides and quinolones were measured in $57 \%$ of the samples (Figure 2). The high rate of detection of antimicrobials is coincident with previous studies of surface water (Kasprzyk-Hordern et al., 2008; Patrolecco et al., 2013). The frequency of detection is probably related to their high use in both human and veterinary medicine (FEDESA, 1999) and consequently their high rates of excretion and low rates of removal in wastewater treatment plants (Petrović et al., 2003).

Overall, the drugs most frequently detected were sulfadiazine and sulfachloropyridazine, which were present in 27 and $22 \%$ of the samples, respectively (Table
4). The concentrations of all drugs detected ranged between 17 and $3,941 \mathrm{ng} / \mathrm{L}$, with the highest concentration being measured for sulfadiazine. The next highest compounds after sulfadiazine were sulfachloropyridazine $(3,826 \mathrm{ng} / \mathrm{L})$ and sulfamethoxypyridazine (905 $\mathrm{ng} / \mathrm{L})$. The relation between maximum concentration and frequency was observed for antimicrobials, in particular for the group of sulfonamides, where $47 \%$ of the samples analyzed were positive for at least one sulfonamide (Table 4 and Figure 2). This is not the first time that the presence of residue of active substances such as sulfonamides has been reported in drinking water systems (Valcárcel et al., 2011; Sun et al., 2015). After sulfonamides, trimethoprim was the most frequently detected drug; it was present in $17 \%$ of the samples, whereas trimethoprim was found in only $2 \%$ of samples of finished drinking water from Canada (Kleywegt et al., 2011). The simultaneous presence of trimethoprim and sulfonamides was confirmed in 5 samples, probably because these drugs are often administered together

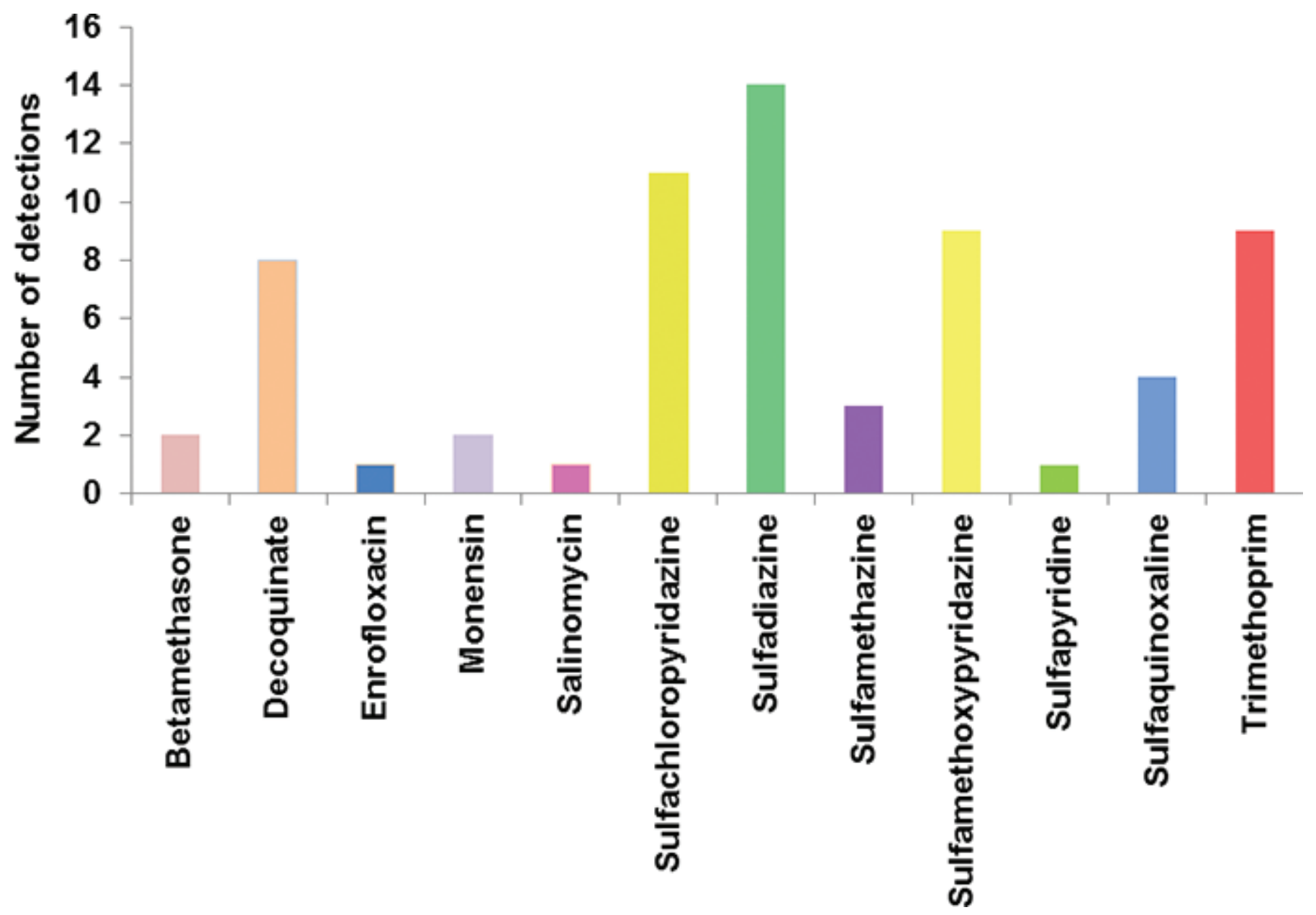

Figure 2. Detection of the veterinary drugs assessed. Color version available online. 
Table 4. Maximum, minimum, average concentrations, and number of detections of the veterinary drugs detected

\begin{tabular}{|c|c|c|c|c|}
\hline \multirow[b]{2}{*}{ Analyte } & \multicolumn{3}{|c|}{ Concentration (ng/L) } & \multirow{2}{*}{$\begin{array}{c}\text { No. of } \\
\text { detection }\end{array}$} \\
\hline & Maximum & Minimum & Average & \\
\hline Betamethasone & 34 & 34 & 34 & 2 \\
\hline Decoquinate & 732 & 17 & 111 & 8 \\
\hline Enrofloxacin & 28 & 28 & 28 & 1 \\
\hline Monensin & 56 & 31 & 44 & 2 \\
\hline Salinomycin & 23 & 23 & 23 & 1 \\
\hline Sulfachloropyridazine & 3,826 & 17 & 716 & 11 \\
\hline Sulfadiazine & 3,941 & 164 & 1,109 & 14 \\
\hline Sulfamethazine & 180 & 29 & 80 & 3 \\
\hline Sulfamethoxypyridazine & 905 & 92 & 184 & 9 \\
\hline Sulfapyridine & 400 & 400 & 400 & 1 \\
\hline Sulfaquinoxaline & 337 & 104 & 110 & 4 \\
\hline Trimethoprim & 552 & 23 & 137 & 9 \\
\hline
\end{tabular}

(Arnold et al., 2014). Trimethoprim was also measured in drinking water from Spain (Valcárcel et al., 2011), the United States (Benotti et al., 2009), China (Sun et al., 2015), and Canada (Kleywegt et al., 2011).

To date, no data indicate clear human health risks associated with the continuous consumption of low levels of pharmaceuticals (ng/L) via drinking water or other type of food because ecotoxicity tests are usually performed using therapeutic doses and short periods of time. However, many investigations have probed toxic effects of pharmaceuticals on large and small terrestrial and aquatic organisms and microorganisms (Wollenberger et al., 2000; Madden et al., 2009; Liu et al., 2011; Miš́́k et al., 2014; Bártiková et al., 2016; Kovacs et al., 2016). For example, lethal and sublethal effects on embryos and larvae of zebrafish exposed to sulfadiazine, sulfamethoxazole, or sulfamethazine have been observed. Concentrations between 1 and 1,000 $\mu \mathrm{g} / \mathrm{L}$ caused toxic effects on spontaneous movements, heartbeats, and hatching of embryos, and resulted in malformations (pericardial edema, yolk sac edema, hemagglutinations, tail deformation, and swim bladder defects) in embryos and larvae (Lin et al., 2013). Ando et al. (2007) investigated the effect of antimicrobials on the growth of 8 cyanobacteria and demonstrated that 7 antimicrobial agents, including sulfadimethoxine and trimethoprim, inhibited the growth of cyanobacteria even at low concentrations. For humans, the continuous ingestion of milk contaminated with low level of antimicrobial via water could lead to the development of resistant bacterial strains as has been shown for animals (Kemper, 2008).

The second most frequently detected group was coccidiostats, present in $20 \%$ of samples; they are also the second most used drug group in veterinary medicine (FEDESA, 1999). Decoquinate was measured in $16 \%$ of samples at concentrations ranging between 17 and 732 $\mathrm{ng} / \mathrm{L}$. As this drug is only used in veterinary medicine, it can be considered an indicator of farming contamination (Iglesias et al., 2013). It is notable that of the 8 samples (15\%) with measurable levels of decoquinate, 5 were sourced from farms using well water. These results could support the idea of lixiviation or runoff of pharmaceuticals after using manure contaminated with decoquinate as fertilizer on agricultural soils. The average concentration of decoquinate $(111 \mathrm{ng} / \mathrm{L})$ was higher than that reported in surface water collected from the same area (23 ng/L; Iglesias et al., 2012), probably due to the degradation effect of decoquinate. Decoquinate is toxic in fetal rats (at $300 \mathrm{mg} / \mathrm{kg}$ of BW per day) with minor developmental variations resulting (retarded skeletal ossification; Boxall et al., 2011). In general, toxicity of coccidiostats for animals is well documented; however, scientific literature does not contain toxicity information for long-term effects at low levels of coccidiostats (ng/L; Hansen et al., 2009). It has also been demonstrated that ionophores might have synergistic effects when combined with other biologically active compounds. The case of cattle death is remarkable because, out of 988 , a total of 562 cattle died $(57 \%)$ in an 8 -wk period due to the consumption of monensin-containing feed contaminated with macrolide antibiotic residues (Basaraba et al., 1999). It has also being shown that narasin combined with nicarbazine is 5 time more toxic than the predicted additive effect (Hansen et al., 2009).

Out of 52 drinking water samples analyzed in the current study, $33(63.5 \%)$ were positive for the presence of one or more drugs. Considering that the mixture of compounds may contribute to the overall effect of the mixture and might increase the toxicity of individual compounds (Arnold et al., 2014), it is important to note that $29 \%$ of the samples contained more than one pharmaceutical; 6 samples were positive for 2 drugs, 
4 samples for 3 drugs, 3 samples were for 4 drugs, 1 sample for 5 drugs, and 1 sample was positive for 6 drugs. One sample contained decoquinate, monensin, sulfachloropyridazine, sulfadiazine, sulfamethazine, and trimethoprim and another sample contained measured levels of sulfachloropyridazine, sulfadiazine, sulfamethoxypyridazine, sulfaquinoxaline, and trimethoprim. Pomati et al. (2008) reported the effect of a mixture of 13 drugs at concentrations in the nanograms per liter range and demonstrated that the mixture could inhibit the proliferation of human embryonic cells by affecting their physiology and morphology. Even if sulfonamides and trimethoprim are often administered simultaneously, adverse reactions to this combination have been reported in humans (Leoung et al., 2001). In the last decade, other research has investigated the adverse effect of pharmaceutical mixtures at the nanograms per liter level (Zou et al., 2012; Vasquez et al., 2014; Wang et al., 2014). Even if effects of mixtures of drugs measured in water collected from milking parlors has not been reported yet, it is likely that these combinations of active substances lead to toxic effects, as has been reported for other groups of drugs (Pomati et al., 2008; Arnold et al., 2014).

When data were analyzed by sampling area, the Coast area (Figure 2) had the fewest contaminated samples; none of the samples analyzed contained residues of the pharmaceuticals at the limit of quantitation of the method used (Table 2). On the other hand, more than $70 \%$ of the samples from the Flatland, Mountain, Center, and South areas were contaminated with drugs. In these areas, the antimicrobials were the most frequently detected - found in more than $50 \%$ of the samples of each area. We noted that the number of contaminated samples by area correlated with the number of farms and total number of cattle by area; the Coast and South areas had fewer farms and cattle, approximately $10 \%$ of the total number of cattle (Figure 1).

The Flatland and Mountain areas had the higher number of samples positive for more than one pharmaceutical; 60 and $57 \%$ of the samples had more than one pharmaceutical in these areas, respectively. In fact, the samples with 5 and 6 pharmaceuticals were collected in farms located in the Flatland area. The Central area

Table 5. Statistical analysis ( $P$-values) of the presence and concentration of each drug detected against sampling area, average sunlight, rainfall, temperature, water source, and sampling month

\begin{tabular}{|c|c|c|c|c|c|c|}
\hline Drug & $\begin{array}{l}\text { Sampling } \\
\text { area }\end{array}$ & $\begin{array}{c}\text { Average } \\
\text { sunlight (h) }\end{array}$ & $\begin{array}{c}\text { Average } \\
\text { rainfall }\left(\mathrm{L} / \mathrm{m}^{2}\right)\end{array}$ & $\begin{array}{c}\text { Average } \\
\text { temperature }\left({ }^{\circ} \mathrm{C}\right)\end{array}$ & $\begin{array}{l}\text { Water } \\
\text { source }\end{array}$ & $\begin{array}{l}\text { Sampling } \\
\text { month }\end{array}$ \\
\hline \multicolumn{7}{|l|}{ Betamethasone } \\
\hline \multicolumn{7}{|l|}{ Decoquinate } \\
\hline Presence & 0.633 & 0.147 & 0.147 & 0.147 & 0.846 & 0.147 \\
\hline Concentration & 0.943 & 0.176 & 0.176 & 0.176 & 0.938 & 0.176 \\
\hline Concentration & 0.117 & 0.199 & 0.199 & 0.199 & 0.587 & 0.199 \\
\hline \multicolumn{7}{|l|}{ Monensin } \\
\hline Presence & 0.898 & 0.295 & 0.294 & 0.295 & 0.434 & 0.294 \\
\hline Concentration & 0.864 & 0.278 & 0.278 & 0.278 & 0.454 & 0.278 \\
\hline \multicolumn{7}{|c|}{ Sulfachloropyridazine } \\
\hline Presence & 0.007 & 0.002 & 0.002 & 0.002 & 0.917 & 0.002 \\
\hline Concentration & 0.226 & 0.003 & 0.003 & 0.003 & 0.797 & 0.003 \\
\hline Concentration & 0.440 & 0.036 & 0.036 & 0.036 & 0.474 & 0.036 \\
\hline \multicolumn{7}{|c|}{ Sulfamethoxypyridazine } \\
\hline Presence & 0.801 & 0.187 & 0.187 & 0.187 & 0.251 & 0.187 \\
\hline Concentration & 0.347 & 0.088 & 0.088 & 0.088 & 0.820 & 0.088 \\
\hline \multicolumn{7}{|l|}{ Sulfapyridine } \\
\hline Presence & 0.675 & 0.199 & 0.199 & 0.199 & 0.587 & 0.199 \\
\hline Concentration & 0.675 & 0.199 & 0.199 & 0.199 & 0.587 & 0.199 \\
\hline \multicolumn{7}{|l|}{ Sulfaquinoxaline } \\
\hline Presence & 0.675 & 0.844 & 0.573 & 0.573 & 0.587 & 0.573 \\
\hline Concentration & 0.675 & 0.573 & 0.573 & 0.573 & 0.587 & 0.573 \\
\hline \multicolumn{7}{|l|}{ Trimethoprim } \\
\hline Presence & 0.375 & 0.606 & 0.606 & 0.606 & 0.674 & 0.606 \\
\hline Concentration & 0.142 & 0.358 & 0.358 & 0.358 & 0.779 & 0.358 \\
\hline
\end{tabular}


had the lowest risk samples: $31 \%$ of the samples did not contain any pharmaceuticals and $60 \%$ only one pharmaceutical. These results are interesting because the Central area had greater numbers of cattle and farms and also the highest number of farms with well water.

In the statistical analysis, the presence and concentration of each drug was evaluated against sampling area; average sunshine, rainfall, and temperature; water source, and sampling month. Table 5 compiles the $P$-values obtained in each case. Significant differences were found for the presence and concentration of sulfachloropyridazine and sulfamethazine with respect to weather conditions and sampling months (Table 5). Sulfamethazine was only detected during February and sulfachloropyridazine was only detected during February and March; these were the months with the lowest recorded average temperature and hours of sunshine. Additionally, higher rainfall was registered during these 2 mo. These results could indicate that sulfamethazine and sulfachloropyridazine were more degraded during April, May, and June by the higher temperatures, more sunshine, and lower rainfall (Table 1).

\section{Microbiological Results}

According to Regulation 853/2004 (EU, 2004), the water used to clean milk facilities must be potable. The Spanish standard Real Decreto 1120/2012 (BOE, 2012) and the World Health Organization (WHO, 2008) state that the number of coliform bacteria in $100 \mathrm{~mL}$ must be zero and the maximum bacterial count at $22^{\circ} \mathrm{C}$ must be $100 \mathrm{cfu} / \mathrm{mL}$. Microbiological analyses of the 52 water samples collected from milking parlors in the current study showed 13 samples to be positive for the presence of coliforms (in a total volume of $100 \mathrm{~mL}$ ), and 10 of these samples came from farms with well water (out of 27 wells analyzed). None of the water samples from farms with distribution systems were positive for coliforms. Higher contamination of well water with coliforms was observed in a study conducted on water quality of private water wells from a farming region in Ohio (United States), where $82 \%(\mathrm{n}=180)$ of the samples were contaminated with coliform bacteria (Won et al., 2013). It is also remarkable that the area in our study with the highest number of total coliforms detected was the Center region (46\%), which also had the greatest number of farms and cattle (Figure 1), These results could indicate a possible relation between ground water contamination and dairy farm contamination but this finding should be investigated in more detail. Regarding mesophilic bacteria, $10 \%$ of samples contained more than $100 \mathrm{cfu} / \mathrm{mL}$; again, such samples are not suitable for use as drinking water for humans and consequently cannot be used in the food industry.
We found no relation between mesophilic bacteria and sample origin or sampling area.

\section{CONCLUSIONS}

Analysis of water samples from milking parlors collected from farms in Galicia (Spain) revealed the presence of pharmaceuticals in $65 \%$ of samples, with the concentration of pharmaceuticals in positive samples ranging between 17 and 3,941 ng/L. Antimicrobials were present in $57 \%$ of the samples, with sulfadiazine and sulfachloropyridazine being the most commonly detected drugs. Coccidiostats were the second most frequently detected group, being present in $20 \%$ of the samples. These 2 groups are the most frequent classes used in veterinary medicine and antimicrobials are the most frequency prescribed drug in human medicine. Considering that a mixture of compounds might increase the toxicity over the additive effect of individual compounds, $29 \%$ of samples contained more than one pharmaceutical. Our results confirm that pharmaceuticals penetrate the human food supply via milking parlors. To date, the effects of continuous consumption of these mixtures of drugs are unknown; however, antimicrobials may affect the human microbiota or have toxic effects in sensitive people. No regulations exist for the presence of pharmaceuticals in drinking water and the long-term effects of low-dose pharmaceuticals need to be investigated. On the other hand, microbiological analyses demonstrated that the water used in most cases is drinkable, and even suitable for human consumption; however, there is evidence of fecal contamination, because $26 \%$ of the samples were positive for total coliforms.

\section{ACKNOWLEDGMENTS}

The authors thank the Xunta de Galicia for funding this study through project (GI-1702; Rumigal: Rede de estudio multidisciplinar dos ruminates en Galicia) and for providing us the water samples. We also thank the staff of the Centro de Apoio Científico e Tecnolóxico of the University of Santiago de Compostela (CACTUS, Lugo, Spain) for their help in analyzing the water samples.

\section{REFERENCES}

Ando, T., H. Nagase, K. Eguchi, T. Hirooka, T. Nakamura, K. Miyamoto, and K. Hirata. 2007. A novel method using cyanobacteria for ecotoxicity test of veterinary antimicrobial agents. Environ. Toxicol. Chem. 26:601-606.

Arnold, K. E., A. R. Brown, G. T. Ankley, and J. P. Sumpter. 2014. Medicating the environment: Assessing risks of pharmaceuticals to wildlife and ecosystems. Phil. Trans. R. Soc. Lond. B Biol. Sci. 369:1-11. 
Ayscough, N., J. Farwell, G. Franklin, and W. Young. 2000. Review of Human Pharmaceuticals in the Environment. Environment Agency, Bristol, UK.

Baquero, F., J. L. Martínez, and R. Cantón. 2008. Antibiotics and antibiotic resistance in water environments. Curr. Opin. Biotechnol. 19:260-265.

Bártíková, H., R. Podlipná, and L. Skálová. 2016. Veterinary drugs in the environment and their toxicity to plants. Chemosphere $144: 2290-2301$.

Basaraba, R. J., F. W. Oehme, M. W. Vorhies, and G. L. Stokka. 1999. Toxicosis in cattle from concurrent feeding of monensin and dried distiller's grains contaminated with macrolide antibiotics. J. Vet. Diagn. Invest. 11:79-86.

Benotti, M. J., B. D. Stanford, E. C. Wert, and S. A. Snyder. 2009. Evaluation of a photocatalytic reactor membrane pilot system for the removal of pharmaceuticals and endocrine disrupting compounds from water. Water Res. 43:1513-1522.

BOE (Boletín Oficial del Estado). 2012. Real Decreto 1120/2012 de Ministerio de la Presidencia de 20 de julio que modifica el Real Decreto 140/2003, de 7 de febrero, por el que se establecen los criterios sanitarios de la calidad del agua de consumo humano. BOE 207:61012-61013

Boxall, A. B. A., K. Tiede, G. Bryning, R. Bevan, C. Tam, and L. S. Levy. 2011. Desk-based study of current knowledge on veterinary medicines in drinking water and estimation of potential levels. Accessed Sep. 10, 2016. http://dwi.defra.gov.uk/research/ completed-research/reports/dwi70-2-235.pdf.

Chang, H., J. Hu, and B. Shao. 2007. Occurrence of natural and synthetic glucocorticoids in sewage treatment plants and receiving river waters. Environ. Sci. Technol. 41:3462-3468.

De Liguoro, M., B. Fioretto, C. Poltronieri, and G. Gallina. 2009. The toxicity of sulfamethazine to Daphnia magna and its additivity to other veterinary sulphonamides and trimethoprim. Chemosphere 75:1519-1524.

Díaz-Cruz, M. S., and D. Barceló. 2006. Determination of antimicrobial residues and metabolites in the aquatic environment by liquid chromatography tandem mass spectrometry. Anal. Bioanal. Chem. 386:973-985.

EU (European Union). 2004. Regulation 853/2004 of the European Parliament and of the Council of 29 April 2004. Laying down specific hygiene rules for food of animal origin. Off. J. L139:55-205.

EU (European Union). 2010. Regulation 37/2010 of 22 December 2009 on pharmacologically active substances and their classification regarding maximum residue limits in foodstuffs of animal origin. Off. J. L15:1-72.

EU (European Union). 2015. Directive (EU) 2015/1787 of 6 October 2015 amending Annexes II and III to Council Directive 98/83/EC on the quality of water intended for human consumption. Accessed Dec. 12，2015. http://eur-lex.europa.eu/legal-content/EN/TXT/ PDF/?uri=CELEX:32015L1787\&from=ES.

Eurostat. 2014. Milk production statistics reports for the European Union. Accessed Apr. 10, 2016. http://ec.europa.eu/eurostat/ statistics-explained/index.php/Milk_and_milk_product_ statistics.

FEDESA. 1998. European Federation of Animal Health. Survey of antimicrobial usage in animal health in the European Union and Switzerland. Accessed Feb. 18, 2106. http://www.ema.europa.eu/ docs/en_GB/document_library/Report/2009/10/WC500005167. pdf.

FEDESA. 1999. European Federation of Animal Health. Antibióticos para animales. Una perspectiva sobre antibióticos, salud animal y el debate sobre la resistencia. Accessed Feb. 18, 2016. http:// veterindustria.com/modules/interes/files/dossier1.pdf.

Hansen, M., K. A. Krogh, E. Björklund, B. Halling-Sørensen, and A. Brandt. 2009. Environmental risk assessment of ionophores. Trends Analyt. Chem. 28:534-542.

IGE. 2014. Instituto Galego de Estatística. Accessed Apr. 22, 2016. http://www.ige.eu/igebdt/selector.jsp?COD $=62 \&$ paxina $=001$ $\& c=0301005$.

Iglesias, A., C. Nebot, J. M. Miranda, B. I. Vázquez, C. M. Abuín, and A. Cepeda. 2013. Determination of the presence of three an- timicrobials in surface water collected from urban and rural areas. Antibiotics (Basel) 2:46-57.

Iglesias, A., C. Nebot, J. M. Miranda, B. I. Vázquez, and A. Cepeda. 2012. Detection and quantitative analysis of 21 veterinary drugs in river water using high-pressure liquid chromatography coupled to tandem mass spectrometry. Environ. Sci. Pollut. Res. Int. 19:32353249

Iglesias, A., C. Nebot, B. I. Vázquez, C. Coronel-Olivares, C. M. F. Abuín, and A. Cepeda. 2014. Monitoring the presence of 13 active compounds in surface water collected from rural areas in northwestern Spain. Int. J. Environ. Res. Public Health 11:5251-5272.

Jjemba, P. K. 2006. Excretion and ecotoxicity of pharmaceutical and personal care products in the environment. Ecotoxicol. Environ. Saf. 63:113-130.

Kasprzyk-Hordern, B., R. M. Dinsdale, and A. J. Guwy. 2008. The occurrence of pharmaceuticals, personal care products, endocrine disruptors and illicit drugs in surface water in South Wales, UK. Water Res. 42:3498-3518.

Kemper, N. 2008. Veterinary antibiotics in the aquatic and terrestrial environment. Ecol. Indic. 8:1-13.

Kleywegt, S., V. Pileggi, P. Yang, C. Hao, X. Zhao, C. Rocks, S. Tharch, and P. Cheung. 2011. Pharmaceuticals, hormones and bisphenol A in untreated source and finished drinking water in Ontario, Canada-Occurrence and treatment efficiency. Sci. Total Environ. 409:1481-1488.

Kosma, C. I., D. A. Lambropoulou, and T. A. Albanis. 2014. Investigation of PPCPs in wastewater treatment plants in Greece: Occurrence, removal and environmental risk assessment. Sci. Total Environ. 466-467:421-438.

Kovács, R., K. Bakos, B. Urbányi, J. Kövesi, G. Gazsi, and A. Csepeli., Á, J. Appl, D. Bencsik, and Á. Horváth. 2016. Acute and sub-chronic toxicity of four cytostatic drugs in zebrafish. Environ. Sci. Pollut. Res. 23:14718-14729.

Leoung, G. S., J. F. Stanford, M. F. Giordano, A. Stein, R. A. Torres, C. A. Giffen, M. Wesley, T. Sarracco, E. C. Cooper, V. Dratter, J. J. Smith, and K. R. Frost. 2001. Trimethoprim-sulfamethoxazole (TMP-SMZ) dose escalation versus direct rechallenge for Pneumocystis carinii pneumonia prophylaxis in human immunodeficiency virus - Infected patients with previous adverse reaction to TMPSMZ. J. Infect. Dis. 184:992-997.

Lin, T., Y. Chen, and W. Chen. 2013. Impact of toxicological properties of sulfonamides on the growth of zebrafish embryos in the water. Environ. Toxicol. Pharmacol. 36:1068-1076.

Liu, B. Y., X. P. Nie, W. Q. Liu, P. Snoeijs, C. Guan, and M. T. Tsui. 2011. Toxic effects of erythromycin, ciprofloxacin and sulfamethoxazole on photosynthetic apparatus in Selenastrum capricornutum. Ecotoxicol. Environ. Saf. 74:1027-1035.

Llena, J. M. 2011. La calidad del agua y sus usos diferentes en ganadería. Selecciones avícolas. Accessed Jan. 15, 2016. http:// veterindustria.com/modules/interes/files/dossier1.pdf.

Madden, J. C., S. J. Enoch, M. Hewitt, and M. T. Cronin. 2009. Pharmaceuticals in the environment: Good practice in predicting acute ecotoxicological effects. Toxicol. Lett. 185:85-101.

MAGRAMA (Ministerio de Agricultura y Medio Ambiente). 2005. "Guía de Prácticas correctas para las ganaderías de vacuno de leche" elaborada por la Organización Interprofesional Láctea (INLAC). Accessed Feb. 3, 2016. http://www.magrama.gob.es/es/ ganaderia/publicaciones/INLAC_tcm7-5982.pdf/.

MAGRAMA (Ministerio de Agricultura y Medio Ambiente). 2014 Estadística Láctea anual. Accessed Feb. 3, 2016. http://www. magrama.gob.es/es/estadistica/temas/estadisticas-agrarias/ ganaderia/estadistica-industrias-lacteas/estadistica-lactea-anual/.

Meteogalicia. 2015. Xunta de Galicia. Consellería de Medio Ambiente, Territorio e Infraestructuras. Climatological statistics reports from Lugo, Galicia, Spain. Accessed Jun. 15, 2016. http://www2. meteogalicia.gal/galego/observacion/estacions/resumostaboas.asp $?$ Nest $=10053$ and $=122 \& y=60 \& r e d=102 \&$ idprov $=0 \#$.

Mišík, M., C. Pichler, B. Rainer, M. Filipic, A. Nersesyan, and S. Knasmueller. 2014. Acute toxic and genotoxic activities of widely used cytostatic drugs in higher plants: Possible impact on the environment. Environ. Res. 135:196-203. 
Patrolecco, L., N. Ademollo, P. Grenni, A. Tolomei, A. B. Caracciolo, and S. Capri. 2013. Simultaneous determination of human pharmaceuticals in water samples by solid phase extraction and HPLC with UV-fluorescence detection. Microchem. J. 107:165-171.

Petrović, M., S. Gonzalez, and D. Barceló. 2003. Analysis and removal of emerging contaminants in wastewater and drinking water. TracTrend. Anal. Chem. 22:685-696.

Pomati, F., C. Orlandi, M. Clerici, F. Luciani, and E. Zuccato. 2008. Effects and interactions in an environmentally relevant mixture of pharmaceuticals. Toxicol. Sci. 102:129-137.

Rodil, R., J. B. Quintana, E. Concha-Graña, P. López-Mahía, S. Muniategui-Lorenzo, and D. Prada-Rodríguez. 2012. Emerging pollutants in sewage, surface and drinking water in Galicia (NW Spain). Chemosphere 86:1040-1049.

Santos, L. H., A. N. Araújo, A. Fachini, A. Pena, C. Delerue-Matos, and M. C. B. S. M. Montenegro. 2010. Ecotoxicological aspects related to the presence of pharmaceuticals in the aquatic environment. J. Hazard. Mater. 175:45-95.

Sun, J., Q. Luo, D. Wang, and Z. Wang. 2015. Occurrences of pharmaceuticals in drinking water sources of major river watersheds, China. Ecotoxicol. Environ. Saf. 117:132-140.

Valcárcel, Y., S. González Alonso, J. L. Rodríguez-Gil, A. Gil, and M. Catalá. 2011. Detection of pharmaceutically active compounds in the rivers and tap water of the Madrid region (Spain) and potential ecotoxicological risk. Chemosphere 84:1336-1348.
Vasquez, M. I., A. Lambrianides, M. Schneider, K. Kümmerer, and D. Fatta-Kassinos. 2014. Environmental side effects of pharmaceutical cocktails: What we know and what we should know. J. Hazard. Mater. 279:169-189.

Wang, J., M. Sánchez-Roselló, J. L. Aceña, C. del Pozo, A. E. Sorochinsky, S. Fustero, V. A. Soloshonok, and H. Liu. 2014. Fluorine in pharmaceutical industry: Fluorine-containing drugs introduced to the market in the last decade (2001-2011). Chem. Rev. $114: 2432-2506$

Watkinson, A. J., E. J. Murby, D. W. Kolpin, and S. D. Costanzo. 2009. The occurrence of antibiotics in an urban watershed: from wastewater to drinking water. Sci. Total Environ. 407:2711-2723.

WHO. 2008. Guidelines for drinking water quality: Incorporating the first and second addenda volume 1: Recommendations. World Health Organization (WHO), Geneva, Switzerland.

Wollenberger, L., B. Halling-Sørensen, and K. O. Kusk. 2000. Acute and chronic toxicity of veterinary antibiotics to Daphnia magna. Chemosphere 40:723-730.

Won, G., A. Gill, and J. T. LeJeune. 2013. Microbial quality and bacteria pathogens in private wells used for drinking water in northeastern Ohio. J. Water Health 11:555-562.

Zou, X., Z. Lin, Z. Deng, D. Yin, and Y. Zhang. 2012. The joint effects of sulfonamides and their potentiator on Photobacterium phosphoreum: Differences between the acute and chronic mixture toxicity mechanisms. Chemosphere 86:30-35. 